Dicle Tıp Dergisi / Dicle Med J (2019) 46 (4) : 821 - 829

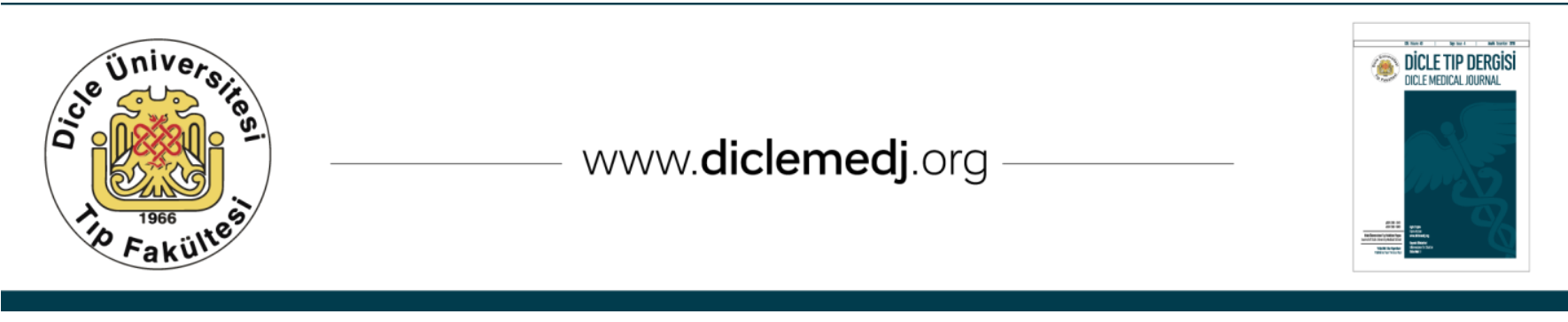

Özgün Araștırma / Original Article

\title{
The importance of clinical and pathological features in bladder cancer and its effects on disease course
}

\author{
Sahin Lacin ${ }^{1}$, Nilgun Sogutcu ${ }^{2}$ \\ 1 Univ of Health Sci, Diyarbakır GaziYasargil Training and Research Hospital, Dept of Medical Oncololgy, Diyarbakır, Turkey ORCID:0000 0002 11600437 \\ 2 Univ of Health Sciences, Diyarbakır GaziYasargil Training and Research Hospital, Dept of Pathology, Diyarbakır, Turkey ORCID:0000 0002 2455 2964
}

Received: 07.10.2019; Revised: 30.10.2019; Accepted: 04.11.2019

\begin{abstract}
Objective: Bladder cancer (BC) is the most common malignancy of the urinary system and the incidence of $\mathrm{BC}$ varies regionally. Bladder cancer is more common in men than in women. Tumor stage and grade are the most important prognostic factors of $\mathrm{BC}$. We aimed to describe the patterns of $\mathrm{BC}$ presentation and to examine the differences in the distribution of prognostic factors by gender, age, tumor size, and involvement region.

Method: The patients diagnosed with BC (non-muscle invasive or muscle-invasive BC) were included. Intravesical treatment, tumor diameter, pathological grade, tumor involved area and tumor stage were recorded as variables. The survival rates of the patients were calculated for diverse clinical and pathological findings.

Results:In a total of 124 patients, $23(18.5 \%)$ of patients were female and 101(81.5\%) of patients were male, the median age of all patients was 64 (IQR: 21-92). There were $36 \%$ (41) patients in early-stage (stage 0 or stage insitu), $50.9 \%(58)$ patients in stage 1, 7\% (8) patients in stage 2, $4.4 \%(5)$ patients in stage 3 and $1.8 \%$ (2) patients were in stage 4 . There were significantly different $\mathrm{OS}$ rates of patients with $\mathrm{BC}$ in different stages $(\mathrm{p}<0.001)$. Tumor diameter in 36 of patients was $<2.5 \mathrm{~cm}$ (group 1) and tumor diameter in 28 patients was $>2.5 \mathrm{~cm}$ (group 2). There was a significant difference between the overall survival rates of group 1 and group $2(\mathrm{p}=0.02)$. There were 55 patients with low-grade $\mathrm{BC}$ and 38 of patients with high-grade $\mathrm{BC}$, and the difference between their survival rates was statistically significant $(\mathrm{p}=0.001)$.

Conclusions: Tumor stage, tumor diameter, and grade were demonstrated and confirmed as the crucial prognostic factors of bladder cancer. Additionally, lateral walls of bladder constitute the most commonly involved area, but their roles in the disease course still remain unclear.
\end{abstract}

Keywords: Bladder cancer, Tumor size, Grade, Stage, Recurrence

DOI: $10.5798 /$ dicletip

Yazıșma Adresi / Correspondence: Nilgun Sogutcu, University of Health Sciences, Diyarbakır GaziYasargil Training and Research Hospital,

Department of Pathology, Diyarbakır, Turkey e-mail: nilgunsogutcu@gmail.com 


\section{Mesane kanserinde klinik ve patolojik özelliklerin önemi ve hastalık seyrine etkisi}

\section{Öz}

Amaç: Mesane kanseri (MK), üriner sistemin en sık görülen malignitesidir ve görülme sıklığı bölgelere göre değişmektedir. Mesane kanseri erkeklerde kadınlardan daha yaygındır. Tümör evresi ve derecesi, MK'nin en önemli prognostik faktörleridir. Bu çalışmamızda mesane kanserinin klinik ve patolojik özelliklerini belirlemeyi, ayrıca bu özelliklerin prognostik değerleri ve hasta sağkalımı üzerine etkilerini incelemeyi amaçladık.

Yöntemler: Çalışmaya mesane kanseri tanısı konan hastalar (kas tutulumu olmayan veya kas tutulumu olan) dahil edildi. Mesane içi tedavi tipi, tümör çapı, patolojik derece, tümörün oluştuğu bölge ve tümör evresi değişken olarak kaydedildi. Hastaların sağkalım oranları; tümör çapı, tümörün histopatolojik derecesi ve hastalığın evresi gibi çeşitli parametrelerle ilişkilendirildi.

Bulgular: Toplam 124 hastanın 23'ü $(\% 18,5)$ kadın, 101'i (\%81,5) erkek, tüm hastaların ortalama yaşı 64 idi (21-92). Erken evrede \%36 (41) hasta (evre 0 veya evre insitu), evre 1'de \%50,9 (58) hasta, evre 2'de \%7 (8), evre 3'te \%4,4 (5) hasta ve evre 4'te \%1,8'i (2) hasta saptandı. Evreler arası sağkalım oranları arasındaki fark istatistiksel olarak anlamlı idi ( $\mathrm{p}<0.001)$. Hastaların 36 'sında tümör çapı $<2.5 \mathrm{~cm}$ (grup 1) ve 28 hastada tümör çapı $>2.5 \mathrm{~cm}$ (grup 2) idi. Grup 1 ile grup 2 arasında genel sağkalım oranları arasında anlamlı bir fark vardı $(p=0,02)$. Düşük dereceli MK'li 55 hasta ve yüksek dereceli MK'li 38 hasta vardı ve sağkalım oranları arasındaki fark istatistiksel olarak anlamlıydı $(\mathrm{p}=$ 0,001).

Sonuç: Tümör evresi, tümör çapı ve derecesi, mesane kanserinin kritik prognostik faktörleri olarak gösterildi ve doğrulandı. Tümör gelişim bölgesi olarak, mesanenin lateral duvarları en sık oluşma alanı olarak saptanmasına rağmen, hastalık seyri üzerindeki etkisi saptanmadı.

Anahtar kelimeler: Mesane kanseri, tümör çapı, histopatolojik derece, sağkalım.

\section{INTRODUCTION}

Bladder cancer (BC) is the most common malignancy of the urinary system and the incidence of $\mathrm{BC}$ changes according to region. $\mathrm{BC}$ is the ninth most common cancer in the world with the highest rates in developed communities ${ }^{1,2}$.There are many different risk factors which have impact on developing of bladder cancer such as chemical carcinogenesis, cigarette smoking, occupational carcinogen exposure, chronic cystitis, radiation therapy, cyclophosphamide, heredity, oncogenes and tumor suppressor genes ${ }^{3}$. Urothelial carcinoma with different grades is the most common histologic type in developed countries, and non-urothelialhistologies are more frequent in developing countries. BC is generally seen in older individuals and the median age of diagnosis is 69 years in men and 71 in women. However, BC can emerge in young patients who are current or heavy smokers ${ }^{4}$. The male gender is predominant in this cancer type, and all subtypes of bladder cancer occurring fewer in women. Gender also has a significant impact on the disease mortality, and women with $\mathrm{BC}$ have poorer survival than male ${ }^{5,6}$.Tumor pathological stage and grade have been reported as the most important prognostic factors, and the presence of them has significant effects on the course of the disease. Additionally, the number of tumor lesions, the frequency of recurrence, tumor size, and the presence or absence of concomitant Tis disease have been assessed as risk factors for the disease prognosis 7,8 .Nonmuscle invasive $\mathrm{BC}$ cases constitute around 70 percent of patients which include $\mathrm{Ta}$ (papillary), Tis (carcinoma in situ) and $\mathrm{T} 1$ (submucosal invasive) tumors ${ }^{9}$. The remaining 30 percent of $\mathrm{BC}$ is found in the muscleinvasive stage of the disease which includes T2 (muscularispropria invasive), T3 (perivesical tissue invasive) or T4 (adjacent pelvic organs or structures invasive) tumors.The standard 
treatment of non-muscle invasive bladder tumors is complete transurethral resection of all visible bladder tumors. Radical cystectomy is the standard and curative treatment of muscle-invasive operable $\mathrm{BC}$, and systemic therapies (chemotherapies or immunotherapies) are used as the initial treatment of patients with inoperable locally advanced or metastatic BC.We aimed to describe the presentation patterns of $\mathrm{BC}$ in our hospital in terms of the tumor grade and stage, and to examine the distribution differences of these prognostic factors according to patient gender, age, tumor diameter, and involved region of bladder and their potential effects on patient survival.

\section{METHODS}

\section{Patients}

This study was approved by Ethics Committee of the institution (date of approval: 08.02.2019, approval no: 221).The patients who diagnosed with bladder lesion (lesion suspicious for nonmuscle invasive or muscle-invasive BC at cystoscopy) whose data were contained within a prospectively maintained database at our hospital between December 2009 to January 2019 were included. The diagnosis of BC was confirmed with specific pathological findings. The inclusion criteria of our study were patients who had bladder lesions based on histopathological and cystoscopic findings in any diameter. Other eligibility criteria were patients aged 18 years or older. Patients were excluded if they did not have enough histopathologic confirmation of bladder tumoral lesions or diagnosed with any other disease that involved bladder rather than primary bladder disease. All patients' treatment decisions had been discussed in the interdisciplinary tumor boards. Concurrent treatment with both systemic and locally were included as study variables. Intravesical treatment, tumor diameter, pathological grade, tumor involved area and tumor stage were recorded as variables. The survival rates of the patients were calculated for diverse clinical and pathological findings. All laboratory parameters of the patients were obtained and patients divided into diverse groups according to their histopathologic type of the disease, stage, tumor size diameter, involvement area.

Overall survival (OS) rate was the primary outcome and calculated from the date of diagnosis to disease-related death or date of last contact with the patient or any family member.

\section{Statistical Analysis}

The Statistical Package for the Social Sciences (SPSS) for Windows version 22.0(IBM Corporation, Somers, New York, USA ) was used. Differences in patient characteristics were compared between those with possible prognostic or predictive factors for suspicious lesions of non-muscle invasive or muscleinvasive BC at cystoscopy. Chi-square or the Fisher's exact test was used to test for statistical differences between the groups. Survival rates were estimated by the KaplanMeier method and the log-rank test was used to compare OS rates between groups. Univariable and multivariable association between survival and the covariates were investigated using the Cox proportional hazards model. Hazard ratios (HRs) with 95\% confidence intervals (CIs) were calculated. $P$ values of lessthanorequalto 0.05 were considered statistically significant.

\section{RESULTS}

\section{Baseline Patient Characteristics}

A total of 124 patients with suspicious bladder lesion in terms of $\mathrm{BC}$ were identified, and they were treated with one or more treatment modality or followed up with the best supportive care (BSC) at our hospital. The demographic and clinical characteristic of the patients at baseline is summarized in table 1 . 
Table I: The relationship between the tumor diameter and grade. Tumor size and Tumor grade

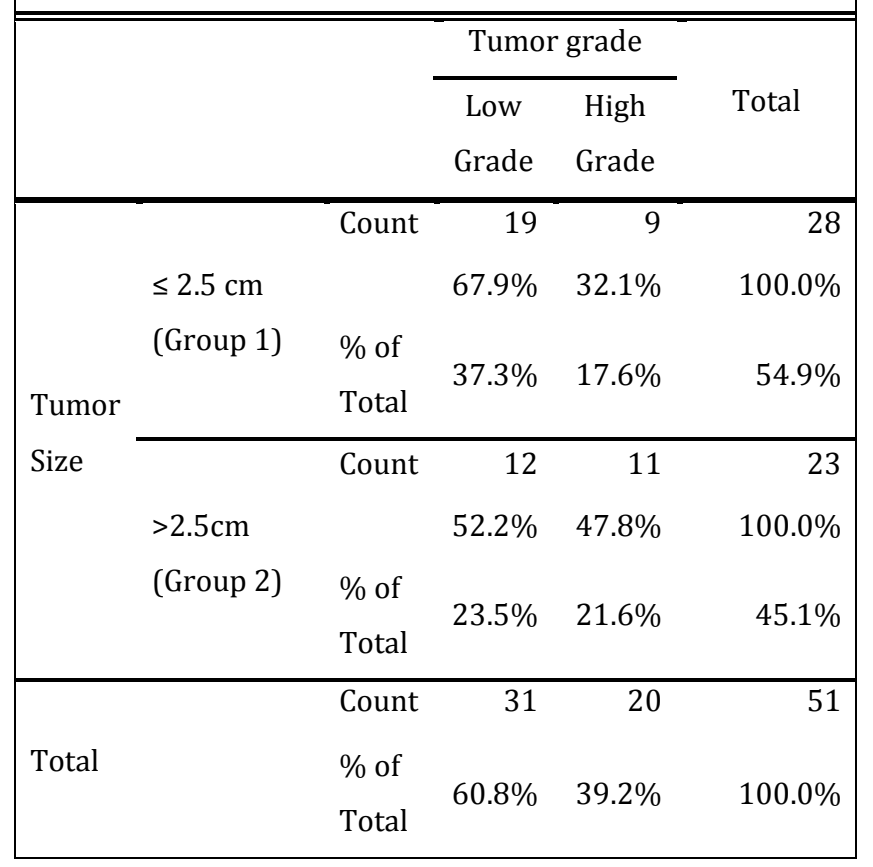

Twenty three $(18.5 \%)$ of patients were female and $101(81.5 \%)$ of patients were male, the median age of 124 patients was 64 (range: 1592). For the patients who were able to be evaluated for the disease stage according to actual staging system, there were 36\%(41) patients classified as early-stage (stage 0 or stage insitu), 50.9\%(58) patients classified as stage 1, 7\% (8) patients classified as stage 2, $4.4 \%(5)$ patients classified as stage 3 and 1.8\% (2) patients were classified as stage 4 . There was a statistically significant difference between $\mathrm{OS}$ rates of patients with $\mathrm{BC}$ at the separate stages, 90 months for patient with stage 1, 48.5 months for patients with stage 2, 14.9 months for patient with stage 3, 13.2 months for patient with stage 4 $(\mathrm{p}<0.001)$ (Figure 1). All the patients were evaluated regarding tumor invasion depth, 38 (33.3\%) of patients had Ta tumor, 3 (2.6\%) of patients had Tis tumor, 58 (50.9\%) of patients had T1 tumor, 13 (11.4\%) of patients had T2 tumor, $1(0.9 \%)$ patient had T3 and $1(0.9 \%)$ patient had T4 tumor. In terms of patient blood type classification, thirty-four (36.2\%) of patients were blood type A, 20 (21.3\%)patient blood type B, 6 (6.4\%) patient blood type $A B$, and $34(36.2 \%)$ patient were blood type 0 . The patient population of the study was divided into two patient groups according to their tumor size diameter and the cut-off value for diameter was determined as $2.5 \mathrm{~cm}$. Thirty-six patients had bladder tumor size diameter less or equal $2.5 \mathrm{~cm}$ (group 1) and 28 patients had bladder tumor lesion size more than $2.5 \mathrm{~cm}$ (group 2).

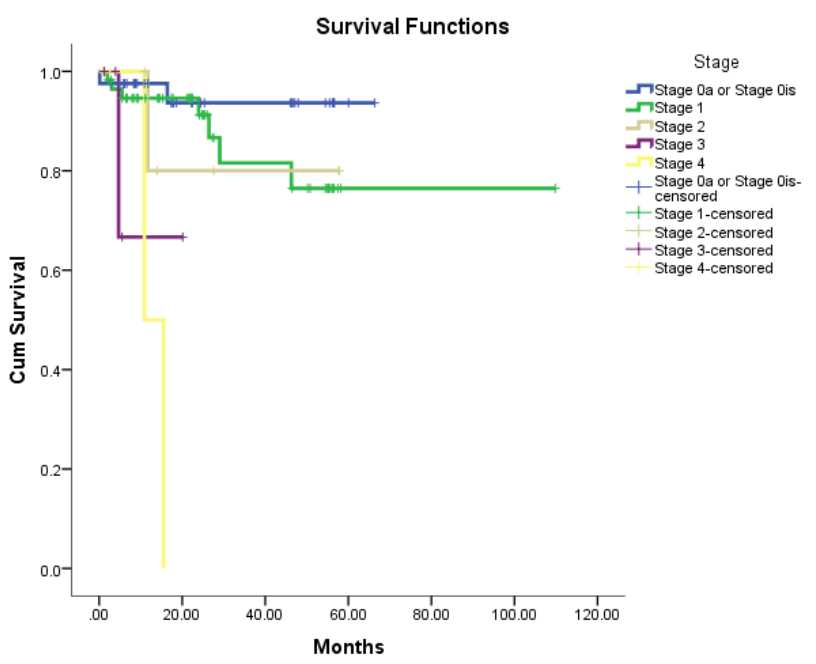

Figure 1: The survival rates of patients with bladder cancer according to their stages were estimated by the Kaplan-Meier.

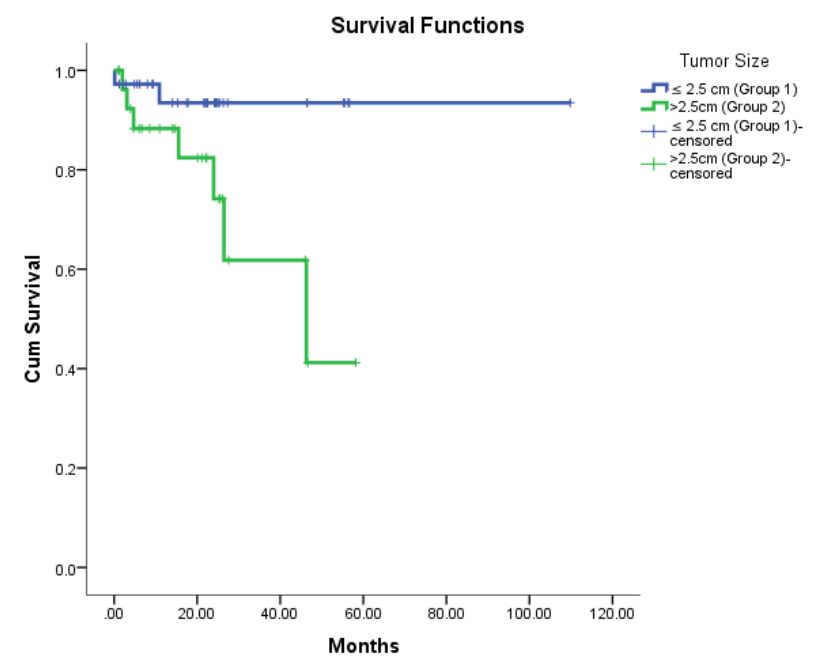

Figure 2: The survival rates of bladder cancer patients according to their tumor size were estimated by the KaplanMeier method. 
There was a significant difference between overall survival rates of group 1 and group 2, the median OS rate of group 1 and group 2 were 103 months and 40 months, respectively $(p=0.02)$ (Figure 2). Female and male patients' survival rates were not significantly different $(\mathrm{p}=0.779)$. Among the patients who had intravesical treatment, $18(62.1 \%)$ of patients had been treated with BCG, 10 (34.5\%) patients had been treated with epirubicin, and 1(3.4\%) patient had been treated with mitomisin. Epirubicin and BCG were the most commonly used intravesical treatments and they were compared with each other in terms of recurrence rates, there was no difference between two treatment arms $(\mathrm{p}=0.42)$ (Figure $3)$.

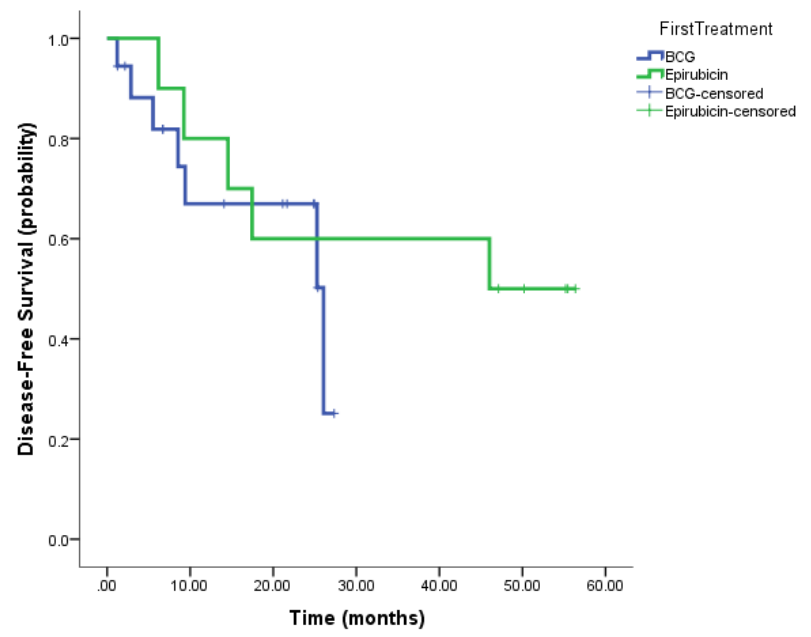

Figure 3: The disease free survival rates of bladder cancer patients according to their intravesical treatment agent were estimated by the Kaplan-Meier method.

In terms of bladder areas that involved by the tumor, the most common involved area was right lateral wall in 26(33.3\%) of patients, and posterior area of bladder was involved in $16(20.5 \%)$ of patients, left lateral wall was involved in 14(17.9\%) of patients, diffuse involvement was detected in $8(10.3 \%)$ of patients, lower area of bladder was involved in $7(9 \%)$ of patients, anterior area of bladder was involved in 5(6.4\%) of patients, and upper area of bladder was involved in $2(2.6 \%)$ of patients (Figure 4).

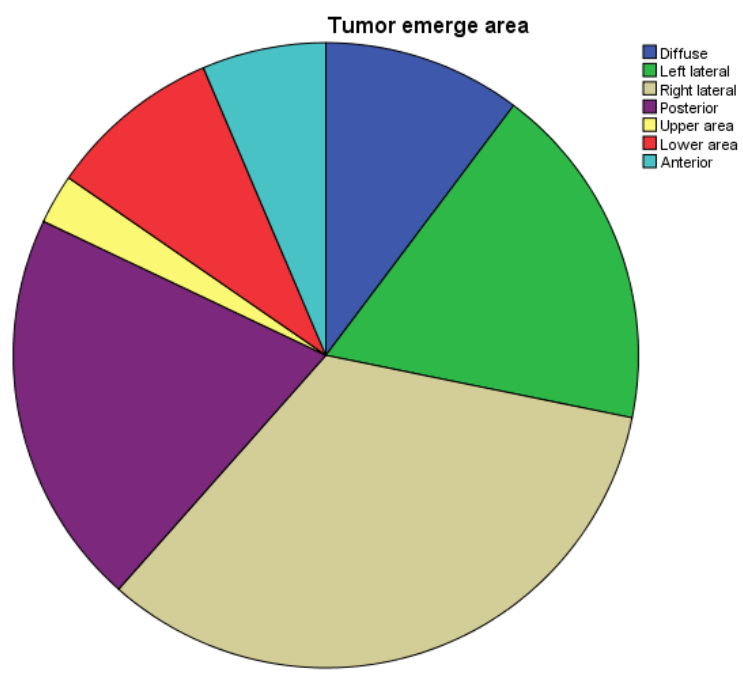

Figure 4: A pie chart demonstrates the proportion of bladder areas that involved by the tumor.

In terms of tumor grade, there were 55 patients with low grade and 38 of patients with highgrade $\mathrm{BC}$, and the difference between their survival rates was statistically significant $(\mathrm{p}=0.001)$. The median OS for the patients with low grade was 102.1 months, 41.2 months for the patients with high grade (Figure 5). There was no statistically significant relation between tumor size and tumor grade $(\mathrm{p}=0.254)$ (Table 1).

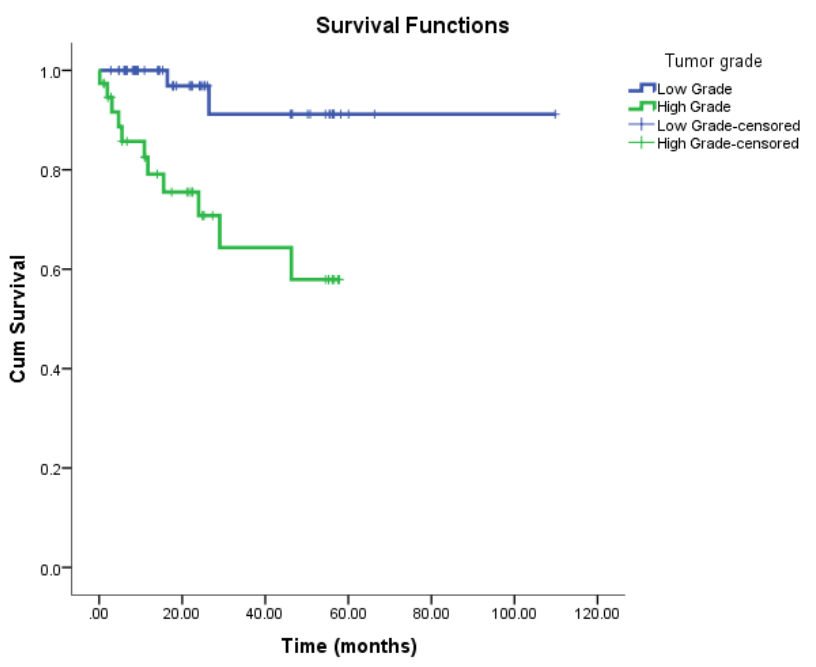

Figure 5: The survival rates of the patients with bladder cancer according to their grade were estimated by the Kaplan-Meier. 
Table II: Demographic and Clinical Characteristics of the Patients at Baseline

\begin{tabular}{|c|c|c|c|}
\hline & Number & Percentage \\
\hline \multicolumn{2}{|c|}{ Total patients(n) } & 124 & $100 \%$ \\
\hline \multicolumn{2}{|c|}{ Median age of all patients } & $64(21-92)$ & $100 \%$ \\
\hline \multirow{2}{*}{ Median age } & Female & $57(32-90)$ & $18.5 \%$ \\
\hline & Male & 64 (21-92) & $81.5 \%$ \\
\hline \multirow{2}{*}{ Gender } & Female & 23 & $18.5 \%$ \\
\hline & Male & 101 & $81.5 \%$ \\
\hline \multirow[t]{2}{*}{ Tumor size } & Tumor size $\leq 2.5 \mathrm{~cm}$ & 36 & $55.4 \%$ \\
\hline & Tumor size $>2.5 \mathrm{~cm}$ & 29 & $44.6 \%$ \\
\hline \multirow{2}{*}{ Tumor grade } & Low grade & 55 & $59.1 \%$ \\
\hline & High grade & 38 & $40.9 \%$ \\
\hline \multirow{3}{*}{$\begin{array}{l}\text { The local } \\
\text { treatment as } \\
\text { the first line }\end{array}$} & BCG & 18 & $62.1 \%$ \\
\hline & Epirubicin & 10 & $34.5 \%$ \\
\hline & Mitomisin & 1 & $3.4 \%$ \\
\hline \multirow{4}{*}{ Blood Type } & A & 34 & $36.2 \%$ \\
\hline & $B$ & 20 & $21.3 \%$ \\
\hline & $\mathrm{AB}$ & 6 & $6.4 \%$ \\
\hline & 0 & 34 & $36.2 \%$ \\
\hline \multirow{6}{*}{$\begin{array}{l}\text { Tumor } \\
\text { invasion } \\
\text { deepness }\end{array}$} & $\mathrm{Ta}$ & 38 & $33.3 \%$ \\
\hline & Tis & 3 & $2.6 \%$ \\
\hline & T1 & 58 & $50.9 \%$ \\
\hline & $\mathrm{T} 2$ & 13 & $11.4 \%$ \\
\hline & T3 & 1 & $0.9 \%$ \\
\hline & $\mathrm{T} 4$ & 1 & $0.9 \%$ \\
\hline \multirow{5}{*}{ Tumor stage } & $\begin{array}{l}\text { Stage } 0 \text { or stage } \\
\text { insitu }\end{array}$ & 41 & $36 \%$ \\
\hline & Stage 1 & 58 & $50.9 \%$ \\
\hline & Stage 2 & 8 & $7 \%$ \\
\hline & Stage 3 & 5 & $4.4 \%$ \\
\hline & Stage 4 & 2 & $1.8 \%$ \\
\hline
\end{tabular}

\section{DISCUSSION}

The incidence of BC that reported in the literature is about 4 times higher in men than in women [10]. Our study demonstrated and confirmed male dominance in $\mathrm{BC}$, and the incidence of the disease according to the patient's gender in our study was consistent with the literature. The prognosis of $\mathrm{BC}$ is affected by many factors such as tumor diameter, tumor grade, depth of invasion and tumor stage, and our study confirmed statistically significant effects of these factors on survival.

The tumor diameter has been reported anddefined as a prognostic factor, and also has been associated with recurrence rate, especially for $3 \mathrm{~cm}$ cut-off value. There is a clear relationship between low recurrence rate, and smaller tumor size and high recurrence rate and larger tumor size. Similarly, tumor diameter was categorized according to different diameter, a significantly lower risk of recurrence was found in patients with tumor smaller than $1 \mathrm{~cm}$ when compared with those with tumor size larger than $2 \mathrm{~cm} .{ }^{11}$. Despite the different cut-off value of tumor diameter that determined, our study had consistent results with the literature and reported a significant difference between survival rates of patients groups which determined according to their tumor diameter, in favor of small tumor diameter. To our best knowledge, this report is one of few rare studies that demonstrated the relationship between tumor diameter and survival rate.

The BC pathologic stage is a critical determinant for disease management and prognosis like all other cancer types ${ }^{12}$.The distinction between muscle-invasive and nonmuscle-invasive carcinoma must be done, and the muscularispropria should always be sampled as part of any endoscopic tumor biopsy or resection to be sure of pathologic stage $^{13}$.Therefore, the pathological $\mathrm{T}$ category is the most important factor for the management of $\mathrm{BC}$, and $\mathrm{BC}$ is divided into two class based on this category.The eighth edition of the tumornode-metastasis (TNM) staging system that included BC staging as well had been published by the American Joint Committee on Cancer 
(AJCC) in 2017, and there was no change in the actual $\mathrm{T}$ categories. However, regional lymph node $(\mathrm{N})$ and distant metastasis (M) categories were revised in the eighth edition ${ }^{14}$.Nonmuscle-invasive disease (stages Ta, Tis, and T1) constitute majority of patients who initially diagnosed with $\mathrm{BC}^{15}$. The five-year survival rate of patients with non-muscle-invasive $B C$ is higher than 88 percent, and the survival rate dramatically decreases in muscle invasive patients which varies from $63 \%$ to $15 \%{ }^{16}$.In this context, our study demonstrated statistically significant different survival rates in our patient population at different stages and muscle invasive status.

The tumor grade is one of the most important predictors of $\mathrm{BC}$ recurrence rate and prognosis $^{7,17}$, and also the well-recognized determinant of therapeutic options. The prognostic effect of the tumor grade varies; patients with low-grade $\mathrm{Ta} \mathrm{BC}$ tend to relapse rather than progression. In a large scale trial, approximately $70 \%$ of patients with low-grade Ta disease relapsed, however, only $2 \%$ of patients progressed to muscle-invasive disease $^{18}$. On the other hand, the incidence of high-grade $\mathrm{Ta}$ lesions is uncommon in superficial bladder cancer, and the high-grade component of the disease is crucial and has significant impact on progression ${ }^{19}$. Despite intravesical treatment, $25 \%$ of patients with high-grade Ta $\mathrm{BC}$ progress to muscle-invasive disease. Therefore, it is well known that the risk of recurrence and progression from nonmuscle invasive tumor to invasive tumor is highest in patients with high-grade bladder cancer ${ }^{20}$.All invasive bladder cancer can be classified as a high-grade disease because up to $96 \%$ of invasive cancers constitute at least some portion of high-grade histology 21 . The survival rate of high-grade $\mathrm{BC}$ is worse than the low-grade, and this study confirms a significant difference between the survival rates of patients with different grades as expected.
Intravesical BCG is the gold standard treatment for high-grade $\mathrm{Ta}$, Tis or $\mathrm{T} 1 \mathrm{BC}$, and significantly reduces the risk of progression ${ }^{22-}$ ${ }^{24}$.However, patients receiving intravesical therapy should be followed very closely in terms of treatment success or failure.Despite one induction and one maintenance application of intravesical BCG treatment, the presence of recurrence or progression in patients with nonmuscle invasive $\mathrm{BC}$ is defined as treatment failure, and these patients must be treated with further treatment options ${ }^{25}$.As reported in the previous trial, intravesical BCG treatment application to patients with non-muscle invasive $\mathrm{BC}$ was the most common treatment in our patient population; also epirubicin was the drug that used as the second common salvage therapeutic agent after the failure of BCG treatment.

The significance of bladder regions that $\mathrm{BC}$ emerges or involve is unknown and about onethird of tumors arise from the bladder trigone, bladder neck, ureteral orifices regions, and the bladder lateral walls. There is limited data in the literature regarding the possible impact of the bladder cancer involving regions on tumor behavior, although some studies suggesting that tumors in the bladder trigone and neck have greater risk for progression ${ }^{26-29}$. A shorter recurrence-free interval was reported in bladder cancer patients with involvement of prostatic urethra, bladder neck, trigone, and posterior wall in a prospective tria ${ }^{30}$. Additionally, worse survival rates were reported in BC patients with involvement bladder neck than other regions ${ }^{27}$. In this study, the most commonly involved region of the bladder was right and left walls and we couldn't show any significant difference between survival rates of patients with different involved regions.

There were some limitations of our study. This study was planned retrospectively and included patients with mostly non-muscle invasive BC. Another important limitation of 
our study is limited patient number, which was insufficient to compare the significance of prognostic and predictive factors of BC stages. The patient distribution not well balanced according to stages, gender and tumor involvement regions. These limitations were associated with the fact of retrospective study at a single center. Therefore, comparisons between groups may have been influenced by possible impacts of the distribution of the patients that enrolled in the study.

In conclusion, our study confirmed the effects of well-known clinical and pathological features that include tumor grade, disease stage, tumor involvement area, and tumor diameter on bladder cancer in our patient population.Although we found a better survival rate for patients with tumors less than $2.5 \mathrm{~cm}$ diameter which is a new value for tumor size,and no difference between the success rate of local treatment types in early-stage BC; these two entities should be confirmed by studies with larger patient numbers.

Conflicts of interest: The authors have noconflict of interests to declare.

Financial Disclosure: The authors declared that this study has received no financial support.

\section{REFERENCES}

1. Ploeg M, Aben KK, KiemeneyLA.The present and future burden of urinary bladder cancer in the world. World J Urol. 2009;27:289-293.

2. Torre LA, Bray F, Siegel RL, Ferlay J, Lortet-Tieulent J, Jemal A. Global cancer statistics, 2012. CA Cancer J Clin. 2015;65:87-108.

3. Jankovic S, Radosavljevic V. Risk factors for bladder cancer. Tumori. 2007; 93:4-12.

4. Hinotsu S, Akaza H, Miki T, et al. Bladder cancer develops 6 years earlier in current smokers: analysis of bladder cancer registry data collected by the cancer registration committee of the Japanese Urological Association. Int J Urol. 2009;16:64-69.
5. Mungan NA, Kiemeney LA, van Dijck JA, van der Poel HG, Witjes JA. Gender differences in stage distribution of bladder cancer. Urology. 2000;55:368-71.

6. Messing EM, Madeb R, Young T, et al. Long-term outcome of hematuria home screening for bladder cancer in men. Cancer. 2006;107:2173-9.

7. Sylvester RJ, van der Meijden AP, Oosterlinck W, et al. Predicting recurrence and progression in individual patients with stage Ta T1 bladder cancer using EORTC risk tables: a combined analysis of 2596 patients from seven EORTC trials. Eur Urol. 2006;49:466-77.

8. Cambier S, Sylvester RJ, Collette L, et al: EORTC Nomograms and Risk Groups for Predicting Recurrence, Progression, and Disease-specific and Overall Survival in Non-Muscle-invasive Stage Ta-T1 Urothelial Bladder Cancer Patients Treated with 1-3 Years of Maintenance Bacillus Calmette-Guerin. Eur Urol. 2016;69:60-9.

9. Kirkali Z, Chan T, Manoharan M, et al: Bladder cancer: epidemiology, staging and grading, and diagnosis. Urology. 2005;66:4-34.

10. Linn JF, Sesterhenn I, Mostofi FK, Schoenberg M. The molecular characteristics of bladder cancer in young patients. J Urol. 1998;159:1493-6.

11. Jancke G, Rosell J, Jahnson S. Impact of tumour size on recurrence and progression in Ta/T1 carcinoma of the urinary bladder. Scand J UrolNephrol. 2011;45:388-92.

12. Amin MB, McKenney JK, Paner GP, et al: ICUD-EAU International Consultation on Bladder Cancer 2012: Pathology. Eur Urol. 2013;63:16-35.

13. Kim W, Song C, Park S,et al. Value of immediate second resection of the tumor bed to improve the effectiveness of transurethral resection of bladder tumor. J Endourol. 2012;26:1059-64.

14. Amin MB, Greene FL, Edge SB, et al. The Eighth Edition AJCC Cancer Staging Manual: Continuing to build a bridge from a population-based to a more "personalized" approach to cancer staging. CA: a cancer journal for clinicians. 2017;67:93-9.

15. Babjuk M, Burger M, Zigeuner R, et al. EAU guidelines on non-muscle-invasive urothelial carcinoma of the bladder: update 2013. Eur Urol. 2013; 64:639-53.

16. Miller KD, Siegel RL, Lin CC, et al. Cancer treatment and survivorship statistics, 2016. CA: a cancer journal for clinicians. 2016;66:271-89.

17. Ajili F, Darouiche A, Chebil M, Boubaker S. The efficiency of the EORTC scoring system for the prediction of recurrence and progression of nonmuscle-invasive bladder cancer treated by bacillus 
Calmette-Guerin immunotherapy. UltrastructPathol. 2013;37:249-53.

18. Holmang S, Hedelin H, Anderstrom C, Holmberg E, Busch C, Johansson SL. Recurrence and progression in low grade papillary urothelial tumors. J Urol. 1999;162:702-7.

19. Heney NM, Ahmed S, Flanagan MJ, et al. Superficial bladder cancer: progression and recurrence. J Urol. 1983;130:1083-6.

20. Lebret T, Bohin D, Kassardjian Z, et al. Recurrence, progression and success in stage Ta grade 3 bladder tumors treated with low dose bacillus Calmette-Guerin instillations. J Urol. 2000;163:63-7.

21. Hubsher CP, Jansen R, Riggs DR, Jackson BJ, Zaslau S. Sacral nerve stimulation for neuromodulation of the lower urinary tract. Can J Urol. 2012; 19:6480-4.

22. Sylvester RJ, van der MA, Lamm DL. Intravesical bacillus Calmette-Guerin reduces the risk of progression in patients with superficial bladder cancer: a meta-analysis of the published results of randomized clinical trials. J Urol. 2002;168:1964-70.

23. Lamm DL. Preventing progression and improving survival with BCG maintenance. Eur Urol. 2000;37:915.

24. May M, Brookman-Amissah S, Roigas J, et al. Prognostic accuracy of individual uropathologists in noninvasive urinary bladder carcinoma: a multicentre study comparing the 1973 and 2004 World Health Organisation classifications. Eur Urol. 2010;57:850-8.
25. Lamm DL, Blumenstein BA, Crissman JD, et al. Maintenance bacillus Calmette-Guerin immunotherapy for recurrent TA, T1 and carcinoma in situ transitional cell carcinoma of the bladder: a randomized Southwest Oncology Group Study. J Urol. 2000;163:1124-9.

26. Xiao GQ, Rashid H. Bladder Neck Urothelial Carcinoma: A Urinary Bladder Subsite Carcinoma With Distinct Clinicopathology. Int J SurgPathol. 2015; 23:517-23.

27. Stephenson WT, Holmes FF, Noble MJ, Gerald KB. Analysis of bladder carcinoma by subsite. Cystoscopic location may have prognostic value. Cancer. 1990;66:1630-5.

28. Wedel SA, Jones J, Tsaur I, et al. Association of intravesical tumor location with metastases to the pelvic lymph nodes in transitional cell cancer of the bladder. Am J Med Sci. 2010;339:341-4.

29. Vukomanovic I, Colovic V, Soldatovic I, Hadzi-Djokic J. Prognostic significance of tumor location in high-grade non-muscle-invasive bladder cancer. Med Oncol. 2012;29:1916-20.

30. Mulders PF, Hoekstra WJ, Heybroek RP, et al Prognosis and treatment of T1G3 bladder tumours. A prognostic factor analysis of 121 patients. Dutch South Eastern Bladder Cancer Study Group. Eur J Cancer. 1994;30A:914-7. 